\title{
Histologic Findings and Amylase Contents of the Pancreas and Parotid Gland of Rats with Experimental Peritonitis or Ileus*
}

\author{
Goro Kakizaki, $\uparrow$ Noboru Noto, $\uparrow$ Yoshiyuki Fujiwara, $\uparrow$ \\ Tetsunosuke Oizumi, $\uparrow$ Takehiko Soeno $\dagger$ and Takayukr \\ SAITO + \\ Department of Surgery, Akita University School of Medicine, \\ Akita $\dagger$ and Department of Surgery, Tohoku University School \\ of Medicine, Sendai $\ddagger$
}

Kakizaki, G., Noto, N., Fumwara, Y., Otzumi, T., Soeno, T. and Saito, T. Histologic Findings and Amylase Content of the Pancreas and Parotid Gland of Rats with Experimental Peritonitis or Ileus. Tohoku J. exp. Med., 1972, 108 (2), 155-164_-. Histologic examination and measurement of amylase content of the pancreas and parotid gland were done on rats with peritonitis or ileus. Histologic findings and amylase content of the parotid gland were normal when the pancreas remained histologically normal in these conditions; while pathologic changes and low amylase content of the parotid gland were brought about when histopathologic findings of the pancreas was induced by peritonitis or ileus experimentally produced. There was no significant relation between serum amylase levels and the grade of histopathologic changes of the pancreas in rats with peritonitis or ileus. -— amylase; pancreatitis; ileus; peritonitis

The authors (Kakizaki et al. 1971, 1972) demonstrated that experimentally produced acute pancreatitis caused atrophic changes and hypofunction of the parotid gland, and that histologic findings and amylase content of the parotid gland changed parallel to the severity of pancreatic lesions in the repairing period of acute pancreatitis.

In the present study of ours, experimental production of perforative peritonitis and intestinal obstruction were made in rats, and histologic examination and measurement of amylase content of the pancreas and parotid gland and measurement of serum amylase values were done.

\section{Materials and Methods}

Twenty-two male rats of the Wistar-strain weighing between $220 \mathrm{~g}$ and $480 \mathrm{~g}$ were used throughout the experiment and divided into the following two groups.

Peritonitis growp: For producing perforative peritonitis, eleven rats were used. Seven rats were laparotomized under ether anesthesia, the duodenum was transected completely at

Received for publication, March 6, 1972.

* Experimental study on the correlation between the pancreas and parotid gland, 3rd Report.

$\uparrow$ Director: Prof. T. Maeta. 
the site about $1 \mathrm{~cm}$ apart from the pylorus, and then the abdomen was closed. Twenty-four hours after the procedure, blood specimens from the abdominal vein were examined for amylase content, and the pancreas and parotid gland were excised for histologic examination and estimation of amylase content (chronic type).

In the remaining four rats, the abdomen was opened under ether anesthesia, the duodenum transected completely at the site about $1 \mathrm{~cm}$ apart from the pylorus, then intestinal contents were led into the abdominal cavity as much as possible and the abdomen was closed. Seven hours after the procedures, amylase content was estimated on serum, pancreatic and parotid tissues and histologic examination of the pancreas and parotid gland was done (acute type).

Ileus group: For producing intestinal obstruction, eleven rats were used. Six rats were laparotomized under ether anesthesia, the intestine was ligated with a silk at the site about $7.5 \mathrm{~cm}$ apart from the pylorus, then the abdomen was closed. Twenty-four hours after the procedures, histologic examination of the pancreas and parotid gland and amylase estimation of the serum, pancreas and parotid gland were done (upper-ligation type).

In the remaining five rats, the abdomen was opened under ether anesthesia, the end of ileum ligated by a silk and the abdomen was closed. Forty-eight hours after the procedures, examination was done on the items mentioned above (lower-ligation type).

Serum amylase was estimated aecording to Somogyi's method (Somogyi 1938), and estimation of amylase in the pancreas and parotid gland was done in the same ways as described in a previous paper of ours (Kakizaki ot al. 1971).

\section{Results}

\section{Peritonitis group}

\section{Chronic type}

\section{Histologic findings}

Pancreas: Exudation and cell infiltration in peripancreatic fatty tissue were moderately noticed and there were no other special findings in all.

Parotid gland: There were no pathologic changes.

Organ amylase value (Table 1)

Pancreas: Amylase values of the pancreas showed normal values ranging from $364 \times 10^{2} \mathrm{mg} / 100 \mathrm{ml}$ to $524 \times 10^{2} \mathrm{mg} / 100 \mathrm{ml}$ with a mean of $408 \times 10^{2} \mathrm{mg} / 100$ $\mathrm{ml}$.

TABLE 1. Organ amylase and serum amylase from rats with peritonitis of chronic type

\begin{tabular}{c|c|c|c|c}
\hline \multirow{2}{*}{$\begin{array}{c}\text { No. } \\
\text { of rats }\end{array}$} & $\begin{array}{c}\text { Body } \\
\text { weight } \\
(\mathrm{g})\end{array}$ & \multicolumn{2}{|c|}{ Organ amylase $(\mathrm{mg} / \mathrm{l00 \textrm {ml } )}$} & $\begin{array}{c}\text { Serum amylase } \\
(\mathrm{mg} / \mathrm{l} 00 \mathrm{ml})\end{array}$ \\
\cline { 3 - 5 } & 360 & Pancreas & Parotid gland & \\
\hline $\mathbf{2}$ & 370 & $372 \times 10^{2}$ & $624 \times 10^{2}$ & 950 \\
3 & 370 & $518 \times 10^{2}$ & $632 \times 10^{2}$ & 810 \\
4 & 350 & $394 \times 10^{2}$ & $1,036 \times 10^{2}$ & 800 \\
5 & 350 & $417 \times 10^{2}$ & $848 \times 10^{2}$ & 838 \\
6 & 370 & $364 \times 10^{2}$ & $820 \times 10^{2}$ & 1,048 \\
7 & 330 & $366 \times 10^{2}$ & $828 \times 10^{2}$ & 996 \\
& & $408 \times 10^{2}$ & $734 \times 10^{2}$ & 770 \\
\hline \multicolumn{2}{c}{ Mean } & & $789 \times 10^{2}$ & 887
\end{tabular}


Parotid gland: Amylase values of the parotid gland showed normal values ranging from $624 \times 10^{2} \mathrm{mg} / 100 \mathrm{ml}$ to $1036 \times 10^{2} \mathrm{mg} / 100 \mathrm{ml}$ with a mean of $789 \times$ $10^{2} \mathrm{mg} / 100 \mathrm{ml}$.

\section{Serum amylase value}

As shown in Table 1, serum amylase values showed subnormal values ranging from $770 \mathrm{mg} / 100 \mathrm{ml}$ to $1,048 \mathrm{mg} / 100 \mathrm{ml}$ with a mean of $887 \mathrm{mg} / 100 \mathrm{ml}$.

Acute type

\section{Histologic findings}

Pancreas: Exudation and cell infiltration in the peripancreatic fatty tissue were moderately or markedly noticed, but no special pathologic changes were found in the pancreas itself.

Parotid gland: Exudation and cell infiltration in the periglandular fatty tissue were moderately noticed, but no special pathologic changes were observed in the parotid gland itself.

Organ amylase value (Table 2)

Pancreas: Amylase values of the pancreas ranged from $332 \times 10^{2} \mathrm{mg} / 100 \mathrm{ml}$ to $437 \times 10^{2} \mathrm{mg} / 100 \mathrm{ml}$ with a mean of $387 \times 10^{2} \mathrm{mg} / 100 \mathrm{ml}$. All were within the normal limits except for No. 11 rat with a little lower values.

TABLE 2. Organ amylase and serum amylase from rats with peritonitis of acute type

\begin{tabular}{c|c|c|c|c}
\hline \multirow{2}{*}{ No. of rats } & $\begin{array}{c}\text { Body } \\
\text { weight } \\
(\mathrm{g})\end{array}$ & \multicolumn{2}{|c|}{ Organ amylase $(\mathrm{mg} / 100 \mathrm{ml})$} & $\begin{array}{c}\text { Serum amylase } \\
(\mathrm{mg} / \mathbf{1 0 0} \mathrm{ml})\end{array}$ \\
\hline 8 & 380 & Pancreas & Parotid gland & 2,300 \\
9 & 390 & $354 \times 10^{2}$ & $644 \times 10^{2}$ & 1,988 \\
10 & 380 & $437 \times 10^{2}$ & $664 \times 10^{2}$ & 2,134 \\
11 & 400 & $426 \times 10^{2}$ & $706 \times 10^{2}$ & 2,341 \\
\hline \multicolumn{2}{c|}{ Mean } & $332 \times 10^{2}$ & $688 \times 10^{2}$ & 2,191 \\
\hline
\end{tabular}

Parotid gland: Amylase values of the parotid gland showed normal values ranging from $644 \times 10^{2} \mathrm{mg} / 100 \mathrm{ml}$ to $706 \times 10^{2} \mathrm{mg} / 100 \mathrm{ml}$ with a mean of $676 \times 10^{2}$ $\mathrm{mg} / 100 \mathrm{ml}$.

\section{Serum amylase value}

As shown in Table 2, serum amylase values showed higher values ranging from $1,988 \mathrm{mg} / 100 \mathrm{ml}$ to $2,341 \mathrm{mg} / 100 \mathrm{ml}$ with a mean of $2,191 \mathrm{mg} / 100 \mathrm{ml}$. 
TABLE 3. Histologic findings of the pancreas and parotid gland from rats with ileus of upper-ligation type

\begin{tabular}{|c|c|c|c|c|c|c|c|}
\hline Organ & Nistologio findings & 12 & 13 & 14 & 15 & 16 & 17 \\
\hline Pancreas & $\begin{array}{l}\text { Atypical arrangement of } \\
\text { glandular cells } \\
\text { Desquamation } \\
\text { Vacuolation of glandular cells } \\
\text { Disappearance of zymogen } \\
\text { granules } \\
\text { Acinar ectasis and ductal } \\
\text { dilatation } \\
\text { Exudation and cell infiltration } \\
\text { in interstitial tissue } \\
\text { Exudation and cell infiltration } \\
\text { in peripancreatic fatty tissue } \\
\text { Hydropic changes of islet cells }\end{array}$ & $\begin{array}{l}(-) \\
(-) \\
(-) \\
(-) \\
(-) \\
(-) \\
(-) \\
(-)\end{array}$ & $\begin{array}{l}(-) \\
(-) \\
(-) \\
(-) \\
(-) \\
(-) \\
(-) \\
(-)\end{array}$ & $\begin{array}{l}(-) \\
(-) \\
(-) \\
(-) \\
(-) \\
(-) \\
(-) \\
(-)\end{array}$ & $\begin{array}{l}(-) \\
(-) \\
(-) \\
(-) \\
(-) \\
(-) \\
(-) \\
(-)\end{array}$ & $\begin{array}{l}(-) \\
(-) \\
(-) \\
(-) \\
(-) \\
(-) \\
(-) \\
(-)\end{array}$ & $\begin{array}{l}(-) \\
(-) \\
(+) \\
(+) \\
(+) \\
(+) \\
(+) \\
(-)\end{array}$ \\
\hline $\begin{array}{l}\text { Parotid } \\
\text { gland }\end{array}$ & $\begin{array}{l}\text { Atypical arrangement of } \\
\text { glandular cells } \\
\text { Desquamation } \\
\text { Vacuolation of glandular cells } \\
\text { Disappearance of zymogen } \\
\text { granules } \\
\text { Ductal dilatation } \\
\text { Acinar atrophy } \\
\text { Exudation and cell infiltration } \\
\text { in interstitial tissue } \\
\text { Exudation and cell infiltration } \\
\text { in periglandular fatty tissue }\end{array}$ & $\begin{array}{l}(-) \\
(-) \\
(-) \\
(-) \\
(-) \\
(-) \\
(-) \\
(-)\end{array}$ & $\begin{array}{c}(-) \\
(-) \\
(-) \\
(-) \\
(-) \\
(-) \\
(-) \\
(-)\end{array}$ & $\begin{array}{c}(-) \\
(-) \\
(-) \\
(-) \\
(-) \\
(-) \\
(-) \\
(-)\end{array}$ & $\begin{array}{c}(-) \\
(-) \\
(-) \\
(-) \\
(-) \\
(-) \\
(-) \\
(-)\end{array}$ & $\begin{array}{c}(-) \\
(-) \\
(-) \\
(-) \\
(-) \\
(-) \\
(-) \\
(-)\end{array}$ & $\begin{array}{c}(+) \\
(-) \\
( \pm) \\
( \pm) \\
(-) \\
(+) \\
(-) \\
(-)\end{array}$ \\
\hline
\end{tabular}

\section{Ileus group}

\section{Upper-ligation type}

\section{Histologic findings (Table 3)}

Pancreas: Histologic findings of the pancreas were normall in all except for No. 17 rat (Fig. 1).

Parotid gland: Histologic findings of the parotid gland were normal in all except for No. 17 rat (Fig. 2).

Organ amylase value (Table 4).

Pancreas: Amylase values of the pancreas ranged from $277 \times 10^{2} \mathrm{mg} / 100 \mathrm{ml}$ to $788 \times 10^{2} \mathrm{mg} / 100 \mathrm{ml}$ with a mean of $551 \times 10^{2} \mathrm{mg} / 100 \mathrm{ml}$. Normal values were noticed in all except for No. 17 rat with a low value of $277 \times 10^{2} \mathrm{mg} / 100 \mathrm{ml}$.

Parotid gland: Amylase values of the parotid gland ranged from $504 \times 10^{2}$ $\mathrm{mg} / 100 \mathrm{ml}$ to $1068 \times 10^{2} \mathrm{mg} / 100 \mathrm{ml}$ with a mean of $831 \times 10^{2} \mathrm{mg} / 100 \mathrm{ml}$. Normal values were noticed in all except for No. 17 rat with a slightly low value of $504 \times$ $10^{2} \mathrm{mg} / 100 \mathrm{ml}$. 


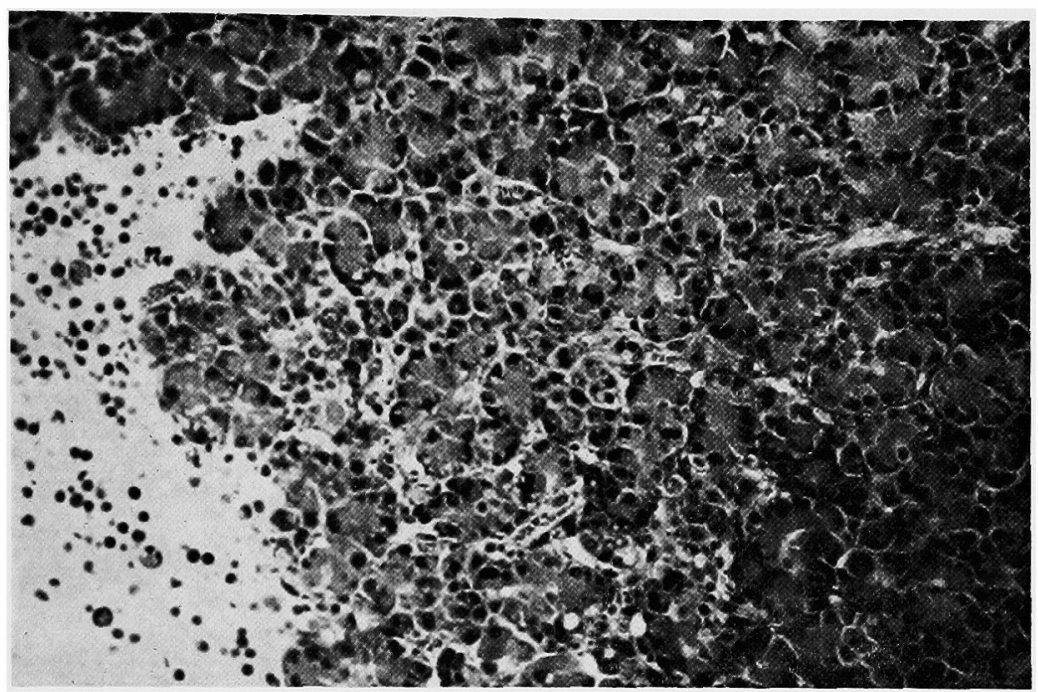

Fig. 1. Photomicrograph of pancreas of No. 17 rat in ileus group. Ductal dilatation, vacuolation of glandular cells and disappearance of zymogen granules with exudation and cell infiltration in interstitial tissue and peripancreatic fatty tissue are noticed. H.E. stain.

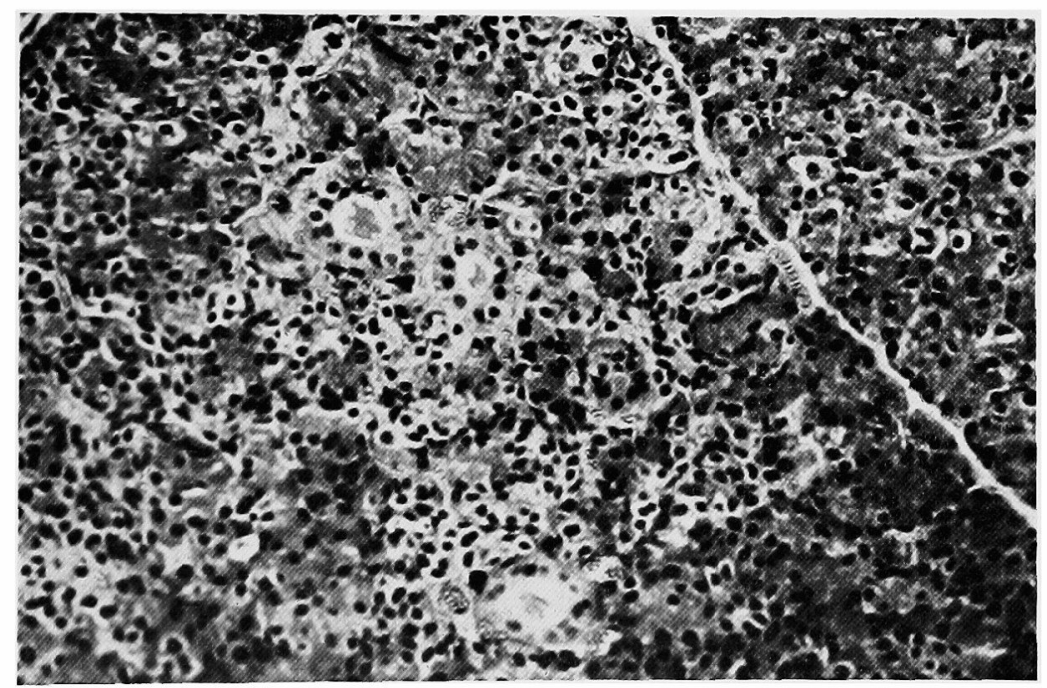

Fig. 2. Photomicrograph of parotid gland of No. 17 rat in ileus group. Atypical arrangement of glandular cells and acinar atrophy are moderately noticed, vacuolized glandular cells being also present. H.E. stain.

\section{Serum amylase value}

As shown in Table 4, serum amylase values showed normal or lower values. In 3 cases (Nos. 12, 15 and 16) the values ranged from $802 \mathrm{mg} / 100 \mathrm{ml}$ to $904 \mathrm{mg} /$ $100 \mathrm{ml}$, and the other three (Nos. 13,14 and 17) showed the values ranging from 
TABLE 4. Organ amylase and serum amylase from rats with ileus of upper-ligation type

\begin{tabular}{c|c|c|c|c}
\hline \multirow{2}{*}{$\begin{array}{c}\text { No. } \\
\text { of rats }\end{array}$} & $\begin{array}{c}\text { Body- } \\
\text { weight } \\
(\mathrm{g})\end{array}$ & \multicolumn{2}{|c|}{ Organ amylase $(\mathrm{mg} / 100 \mathrm{ml})$} & $\begin{array}{c}\text { Serum amylase } \\
(\mathrm{mg} / \mathrm{l} 00 \mathrm{ml})\end{array}$ \\
\cline { 3 - 5 } 12 & 430 & Pancreas & Parotid gland & 857 \\
13 & 330 & $508 \times 10^{2}$ & $846 \times 10^{2}$ & 1,435 \\
14 & 420 & $666 \times 10^{2}$ & $836 \times 10^{2}$ & 1,219 \\
15 & 350 & $788 \times 10^{2}$ & $864 \times 10^{2}$ & 802 \\
16 & 360 & $672 \times 10^{2}$ & $866 \times 10^{2}$ & 904 \\
17 & 340 & $394 \times 10^{2}$ & $1,068 \times 10^{2}$ & 1,186 \\
\hline \multicolumn{2}{c}{ Mean } & $277 \times 10^{2}$ & $504 \times 10^{2}$ & 1,067 \\
\hline
\end{tabular}

$1186 \mathrm{mg} / 100 \mathrm{ml}$ to $1435 \mathrm{mg} / 100 \mathrm{ml}$. A mean of $1067 \mathrm{mg} / 100 \mathrm{ml}$ was obtained in this group.

\section{Lower-ligation type}

\section{Histologic findings}

Pancreas: As shown in Table 5, pathologic histologic findings of the pancreas were noticed in No. 18 and No. 19 rats (Figs. 3 and 4), but no special changes in other three rats.

Parotid gland: As shown in Table 5, pathologic histologic findings of the parotid gland were noticed in No. 19 rat (Fig. 5), but no special changes in others.

Organ amylase value: (Table 6)

Pancreas: Amylase values of the pancreas ranged from $226 \times 10^{2} \mathrm{mg} / 100 \mathrm{ml}$

TABLE 5. Histologic findings of the pancreas and parotid gland from rats with ileus of lower-ligation type

\begin{tabular}{|c|c|c|c|c|c|c|}
\hline Organ & Histologic findings No. of rats & 18 & 19 & 20 & 21 & 22 \\
\hline Pancreas & $\begin{array}{l}\text { Atypical arrangement of glandular cells } \\
\text { Desquamation } \\
\text { Vacuolation of glandular cells } \\
\text { Disappearance of zymogen granules } \\
\text { Acinar ectasis and ductal dilatation } \\
\text { Exudation and cell infiltration in } \\
\text { interstitial tissue } \\
\text { Exudation and cell infiltration in } \\
\text { peripancreatic fatty tissue } \\
\text { Hydropic changes of islet cells }\end{array}$ & $\begin{array}{l}( \pm) \\
(-) \\
(+) \\
(+) \\
(+) \\
(+) \\
(-) \\
(-)\end{array}$ & $\begin{array}{l}(+) \\
(-) \\
(H) \\
(H) \\
(H) \\
(H) \\
(H) \\
(-)\end{array}$ & $\begin{array}{l}(-) \\
(-) \\
(-) \\
(-) \\
(-) \\
(-) \\
(-) \\
(-)\end{array}$ & $\begin{array}{l}(-) \\
(-) \\
(-) \\
(-) \\
(-) \\
(-) \\
(-) \\
(-)\end{array}$ & $\begin{array}{l}(-) \\
(-) \\
(-) \\
(-) \\
(-) \\
(-) \\
(-) \\
(-)\end{array}$ \\
\hline $\begin{array}{l}\text { Parotid } \\
\text { gland }\end{array}$ & $\begin{array}{l}\text { Atypical arrangement of glandular cells } \\
\text { Desquamation } \\
\text { Vacuolation of glandular cells } \\
\text { Disappearance of zymogen granules } \\
\text { Ductal dilatation } \\
\text { Acinar atrophy } \\
\text { Exudation and cell infiltration in } \\
\text { interstitial tissue } \\
\text { Exudation and cell infiltration in } \\
\text { periglandular fatty tissue }\end{array}$ & $\begin{array}{l}(-) \\
(-) \\
(-) \\
(-) \\
(-) \\
(-) \\
(-) \\
(-)\end{array}$ & $\begin{array}{l}(+) \\
(-) \\
(+) \\
(+) \\
(-) \\
(+) \\
(+) \\
(+)\end{array}$ & $\begin{array}{l}(-) \\
(-) \\
(-) \\
(-) \\
(-) \\
(-) \\
(-) \\
(-)\end{array}$ & $\begin{array}{l}(-) \\
(-) \\
(-) \\
(-) \\
(-) \\
(-) \\
(-) \\
(-)\end{array}$ & $\begin{array}{l}(-) \\
(-) \\
(-) \\
(-) \\
(-) \\
(-) \\
(-) \\
(-)\end{array}$ \\
\hline
\end{tabular}




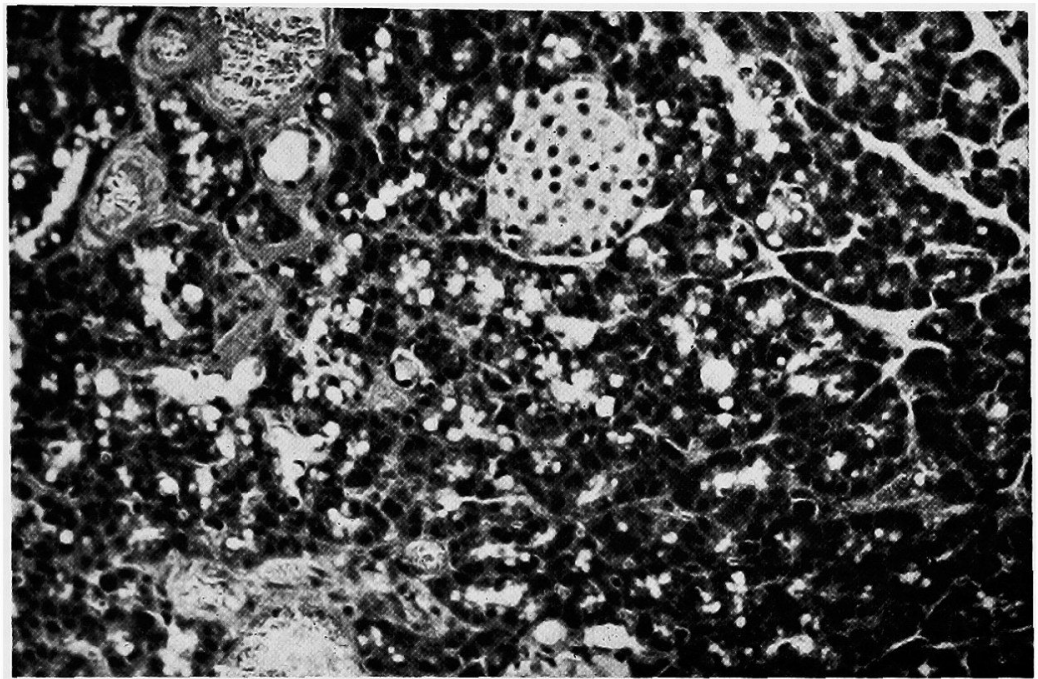

Fig. 3. Photomicrograph of pancreas of No. 18 rat in ileus group. Ductal dilatation and acinar ectasis are markedly noticed, and vacuolation of glandular cells and disappearance of zymogen granules are also present. H.E. stain.

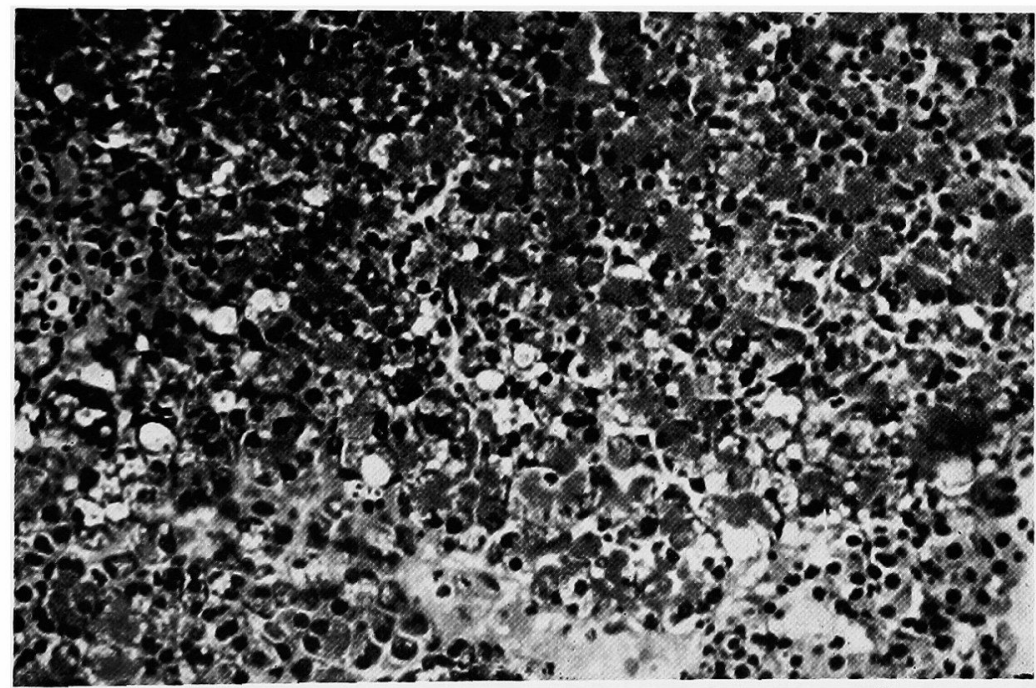

Fig. 4. Photomicrograph of pancreas of No. 19 rat in ileus group. Ductal dilatation, vacuolation of glandular cells, disappearance of zymogen granules, and exudation and cell infiltration in interstitial tissue are markedly noticed. H.E. stain.

to $654 \mathrm{mg} / 100 \mathrm{ml}$ with a mean of $487 \times 10^{2} \mathrm{mg} / 100 \mathrm{ml}$. No. 19 rat showed markedly lower values of $226 \times 10^{2} \mathrm{mg} / 100 \mathrm{ml}$. No. 18 rat had a little lower values of $330 \times 10^{2} \mathrm{mg} / 100 \mathrm{ml}$ and the others were of normal values.

Parotid gland: Amylase values of parotid gland ranged from $436 \times 10^{2} \mathrm{mg} / 100$ 


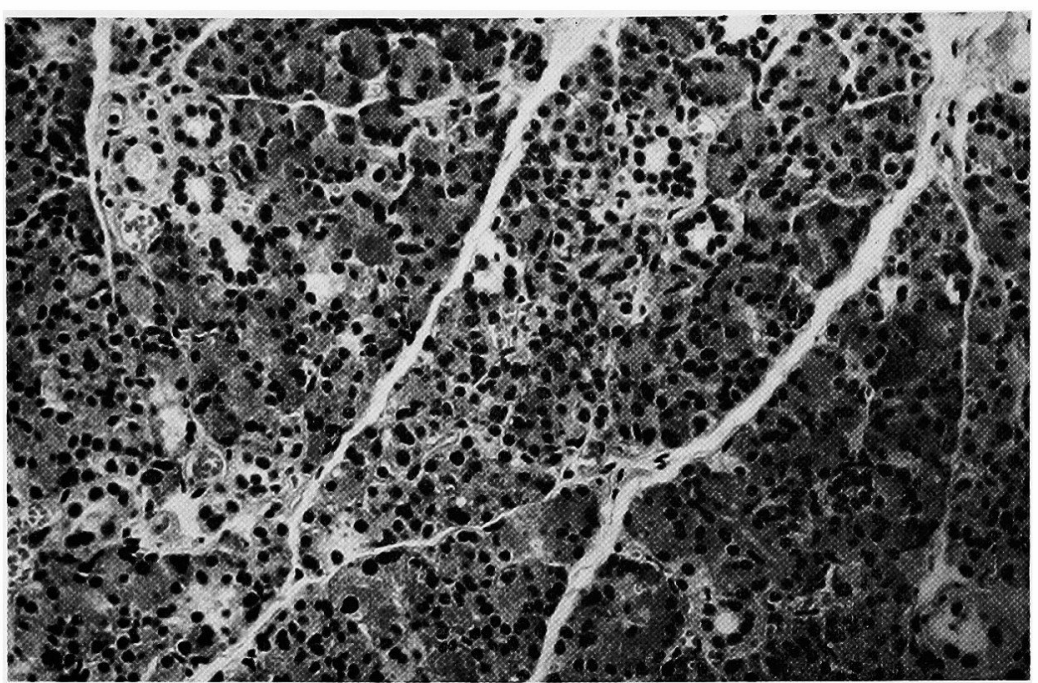

Fig. 5. Photomicrograph of parotid gland of No. 19 rat in ileus group. Atypical arrangement of glandular cells, acinar atrophy and disappearance of zymogen granules are markedly noticed and vacuolation of glandular cells are also present. H.E. stain.

TABLE 6. Organ amylase and serum amylase from rats with ileus of lower-ligation type

\begin{tabular}{|c|c|c|c|c|}
\hline \multirow{2}{*}{$\begin{array}{l}\text { No. } \\
\text { of rats }\end{array}$} & \multirow{2}{*}{$\begin{array}{l}\text { Body- } \\
\text { weight } \\
\text { (g) }\end{array}$} & \multicolumn{2}{|c|}{ Organ amylase $(\mathrm{mg} / 100 \mathrm{ml})$} & \multirow{2}{*}{$\begin{array}{l}\text { Serum amylase } \\
(\mathrm{mg} / 100 \mathrm{ml})\end{array}$} \\
\hline & & Pancreas & Parotid gland & \\
\hline $\begin{array}{l}18 \\
19 \\
20 \\
21 \\
22\end{array}$ & $\begin{array}{l}320 \\
480 \\
440 \\
480 \\
320\end{array}$ & $\begin{array}{l}330 \times 10^{2} \\
226 \times 10^{2} \\
584 \times 10^{2} \\
654 \times 10^{2} \\
642 \times 10^{2}\end{array}$ & $\begin{array}{r}1,088 \times 10^{2} \\
436 \times 10^{2} \\
1,086 \times 10^{2} \\
1,210 \times 10^{2} \\
670 \times 10^{2}\end{array}$ & $\begin{array}{l}1,333 \\
1,340 \\
1,692 \\
1,644 \\
1,407\end{array}$ \\
\hline \multicolumn{2}{|c|}{ Mean } & $487 \times 10^{2}$ & $898 \times 10^{2}$ & 1,487 \\
\hline
\end{tabular}

$\mathrm{ml}$ to $1,088 \times 10^{2} \mathrm{mg} / 100 \mathrm{ml}$ with a mean of $898 \times 10^{2} \mathrm{mg} / 100 \mathrm{ml}$. Normal values were noticed in all except for No. 19 rat with a low value.

\section{Serum amylase value}

As shown in Table 6, serum amylase values ranged from $1333 \mathrm{mg} / 100 \mathrm{ml}$ to $1692 \mathrm{mg} / 100 \mathrm{ml}$ with a mean of $1487 \mathrm{mg} / 100 \mathrm{ml}$. Normal values were noticed in all except for No. 20 and No. 21 rats with higher values.

\section{Discussion}

Results of our present investigation using rats revealed that, 1) in the case of experimentally produced peritonitis, histologic findings and amylase content of the pancreas and parotid gland were found normal, and serum amylase levels showed no significant relation to pathologic changes of the pancreas; 2) in the case of experimentally produced ileus, histologic findings and amylase content of the 
parotid gland were normal when the pancreas was normal in histologic findings, while pathologic changes and low amylase content of the parotid gland were observed when histologic findings of the pancreas were abnormal; and there was no significant relation between histologic findings of the pancreas and serum amylase levels.

Decrease in serum amylase has been observed in adreno-cortical stress (Howard et al. 1955), hepatocellular disease (Cummins and Bockus 1951), and following the administration of propylthiouracil (Challis et al. 1957), in addition to advanced pancreatic parenchymal destruction (Popper and Plotke 1941, Howard et al. 1955). On the other hand, serum amylase elevations have been reported in a number of situations in which there is no pancreatic affection. They include diseases of biliary tract (Lewison 1941, Smith et al. 1952, Pfeffer et al. 1953), penetrating and perforated peptic ulcer (Hinton 1934, Probstein et al. 1939, Pemberton et al. 1950, Malinowski 1952, Mahaffey et al. 1955), intestinal obstruction (Polowe 1943, Raffensperger 1951, Byrne and Boyd 1957), bowel transection (Schneewind 1956), renal insufficiency (Sachar 1952), mumps (Dunlop 1933, Zelman 1944, Candel and Wheelock 1946), and others. Our experimental results concerning serum amylase showed the followings. In experimentally produced perforative peritonitis, the chronic type showed lower values and the acute type higher values of serum amylase associated with normal histologic findings of the pancreas. In experimentally produced intestinal obstruction, upper-ligation type showed normal or lower values and lower-ligation type normal or higher values independent of pancreatic changes. Namely, serum amylase values were not significantly related to the pancreatic changes.

Thus it might be assumed that perforative peritonitis or intestinal obstruction, experimentally produced in rats, did not exert a direct effect upon histologic changes of the parotid gland and that, only when pathologic changes of the pancreas were induced in these conditions, pathologic changes and low amylase content of the parotid gland were brought about. Furthermore, it was observed that there was no significant relation between serum amylase levels and histologic changes of the pancreas of rats with peritonitis or ileus, both of which were experimentally produced.

\section{References}

1) Byrne, J.J. \& Boyd, T.F. (1957) Serum amylase levels in experimental intestinal obstruction. New Engl. J. Med., 256, 1176-1179.

2) Candel, S. \& Wheelock, M.C. (1946) Serum amylase and serum lipase in mumps. Ann. intern. Med., 25, 88-96.

3) Challis, T.W., Reid, L.C. \& Hinton, J.W. (1957) Study of some factors which influence the level of serum amylase in dogs and humans. Gastroenterology, 33, 818822.

4) Cummins, A.J. \& Bockus, H.L. (1951) Abnormal serum pancreatic enzyme values in liver disease. Gastroenterology, 18, 518-529.

5) Dunlop, G.A. (1933) The diastatic index in acute parotitis. Lancet, 225, 183-184.

6) Hinton, J.W. (1934) Chronic pancreatitis associated with peptic ulcer. Arch. Surg., 28, $580-588$. 
7) Howard, J.M., Frawley, J.P. \& Artz, C.P. (1955) A study of plasma amylase activity in the combat casualty. The systemic response to injury. Ann. Surg., 141, 337341.

8) Kakizaki, G., Noto, N. Onuma, T., Saito, T. \& Izumi, S. (1971) Experimental study on the correlation between the pancreas and parotid gland, lst Report: Effect of acute pancreatitis on the parotid gland from the view point of histologic finding and amylase level. Tohoku $J$. exp. Med., 105, 223-231.

9) Kakizaki, G., Noto, N., Fujiwara, Y., Oizumi, T., Soeno, T. \& Saito, T. (1972) Experimental study on the correlation between the pancreas and parotid gland, 2nd Report: Histologic findings and amylase content of the parotid gland of rats with recovery from acute pancreatitis. J. exp. Med., 108,

10) Lewison, E.F. (194I) The clinical value of the serum amylase test. Surg. Gynec. Obstet., 72, 202-212.

11) Malinowski, T.S. (1952) Clinical value of serum amylase determination. J. Amer. Ass., 149, 1380-1385.

12) Mahaffey, J.H., Brokman, H.L., Jordan, G.L. \& Howard, J.M. (1955) A study of the serum amylase concentration in patients with acute perforation of gastroduodenal ulcers. Surg. Gynec. Obstet., 101, 129-132.

13) Pemberton, A.H., Grindley, J.H. \& Bollman, J.L. (1950) Serum amylase levels after acute perforations of the duodenum: Preliminary Report. Proc. Staff. Meet. Mayo Clin., 25, 5-8.

14) Pfeffer, R.B., Stephenson, H.E. \& Hinton, J.W. (1953) Effect of morphine, demerol and codeine on serum amylase values in man. Gastroenterology, 23, 482-486.

15) Popper, H.L. \& Plotke, F. (1941) Studies on pancreatitis: Observations on the disappearance of experimentally increased blood amylase and lipase. Surgery, 9 , 706-711.

16) Polowe, D. (1943) Blood amylase. Amer. J. clin. path., 13, 288-301.

17) Probstein, J.G., Wheeler, P.A. \& Gray, S.H. (1939) Perforated peptic ulcer: Its differentiation form acute pancreatitis by blood diastase determination. $J$. Lab. clin. Med., 24, 449-452.

18) Raffensperger, E.C. (1951) Elevated serum pancreatic enzyme values without primary intrinsic pancreatic disease. Ann. intern. Med., 35, 342-351.

19) Sachar, L.A. (1952) A simplified laboratory test for acnte pancreatitis. Amer. $J$. clin. Path. 22, 1117-1125.

20) Schneewind, J.H. (1956) Effect of experimental bowel transection on serum amylase levels. Surgery, 40, 778-783.

21) Smith, J.L., Walters, R.L. \& Beal, J.M. (1952) A study of choledochal sphincter action. Gastroenteralogy, 20, 129-137.

22) Somogyi, M. (1938) Micromethods for the estimation of diastase. J. biol. Chem., 125, 399414.

23) Zelman, L.S. (1944) Blood diastase values in mumps and mumps pancreatitis. Amer. J. med. Sci., 207, 461-464. 